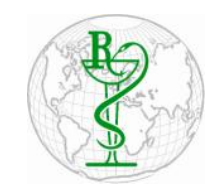

INDO GLOBAL JOURNAL OF

PHARMACEUTICAL SCIENCES

ISSN 2249- 1023

\title{
Phytosome as a Prominent Option in Drug Delivery for the Treatment of the Diseases: A Review
}

\author{
Aloisio Mateus Fiuza Sanha, Parmod Kumar Sharma, Satyender Kumar * \\ Department of Pharmaceutical Sciences, School of Medical and Allied Sciences, Galgotias University, Greater Noida, Uttar Pradesh, India
}

\begin{abstract}
Address for Correspondance Satyender Kumar, $\underline{\text { mateusfsanha9 }}$ $\underline{3 @ \text { gmail.com; }}$ sjinagal@gma

il.com; pkspharmacy @gmail.com
\end{abstract}

Received: 22.02.2018

Accepted:

18.03.2018

\begin{abstract}
Phytosome is made up of two words and expressed the meaning of "Phyto" means plant and "some" means cell-like. Phytosome, is a developing field which is related to phyto-pharmaceuticals and in which the phytoconstituents of herbal extract bounded with the lipid layer. Water is a universal solvent for most of the bioactive phytoconstituents and lipids are lipophilic. Due to this combination of solubility parameter, Phytosome shows better absorption which leads to better bioavailability than the conventional herbal extracts and increases in the pharmacological and pharmacokinetic properties. This characteristic of Phytosome makes more useful in drug delivery system for the disease treatment. The present review represents the recent advances and applications of herbal extract Phytosome as a tool of drug delivery in the treatment of the diseases. () 2018 iGlobal Research and Publishing Foundation. All rights reserved.
\end{abstract}

Cite this article as: Sanha, A.M.F.; Sharma, P.K.; Kumar, S. Phytosome as a prominent option in drug delivery for the treatment of the diseases: a review. Indo Global J. Pharm. Sci., 2018; 8(3): 119-123.

Keywords Drug Delivery; Phytosome; Phospholipids; Bioavailability.

\section{INTRODUCTION}

Over the past few time, the composition of Phytochemical and phyto-pharmacological sciences established which increased the biological activities and health promoting benefits of various botanical products. ${ }^{1}$ The major drawback of plant extracts is their inability to properly cross the lipid membrane and deliver the drug at specific site of action. Phospholipids represent a key agent for the development of phytopharmaceuticals due to its biocompatibility with the phytohemicals. ${ }^{2}$ Phytoconstituents like flavonoids (anthocyanidins from bilberry, catechins from green tea, silymarin from milk thistle) and glycosides etc. which are responsible for anti-diabetic activity, having less absorption by poor passive diffusion due to high molecular weight and less lipid soluble which restrict them to pass across the lipid-rich biological membranes. These factors leads to poor bioavailability of the phytochemicals which can be converted into lipid-compatible molecular complexes called as phytosome. ${ }^{1}$ Phosphatidylcholine, is a bifunctional compound which is miscible in water and oil both and shows good absorption when taken by mouth. The most widely used phospholipid to make Phytosome and obtained from the biological source soybean (Glycine max). The phytosome formulation obtained from Ginkgo biloba, grape seed, green tea, milk thistle hawthorn and ginseng, have efficiently proven the increase in bioavailability and good therapeutic effect in the treatment of Diabetes. ${ }^{3,4}$ The phytosome technology could be a breakthrough model for better clinical result, drug delivery to the tissues, nutrient safety and enhanced bioavailability. ${ }^{1}$

\section{Principle of Phytosome}

Phosphatidylcholine is an effective emulsifier because it consists of head or hydrophilic moiety choline (serine) and a tail or lipophilic moiety phosphatidyl. Hence, the 
Indo Global Journal of Pharmaceutical Sciences, 2018; 8(3): 119-123

phosphotidylcholineproduce a lipid compatible molecular complex with phytoconstituents.

\section{Differences between Phytosome and Liposome:}

Some of the differences between Phytosome and Liposome are mentioned below:

- Liposomes are reported for the delivery vehicles only for dietary supplements and not promising clinical efficacy but Phytosome products numerous studies proved better absorbtion and clinical efficacy. ${ }^{1}$

- Phytosome represent a unit of bonded hybrid molecules, while the liposome represents a group of many phospholipids molecules which encloses phytoactive molecules without specifically bonding. ${ }^{1,5-7}$

In liposome the active principle is dissolved in the medium contained in the cavity or in the layers of the membrane, whereas in the phytosome it is an integral part of the membrane, being the molecules anchored through chemical bonds to the polar head of the phospholipids. ${ }^{8,9}$

The complex formation for the liposome (upper segment) versus phytosome (lower segment)as shown below in Figure $1 .^{6}$

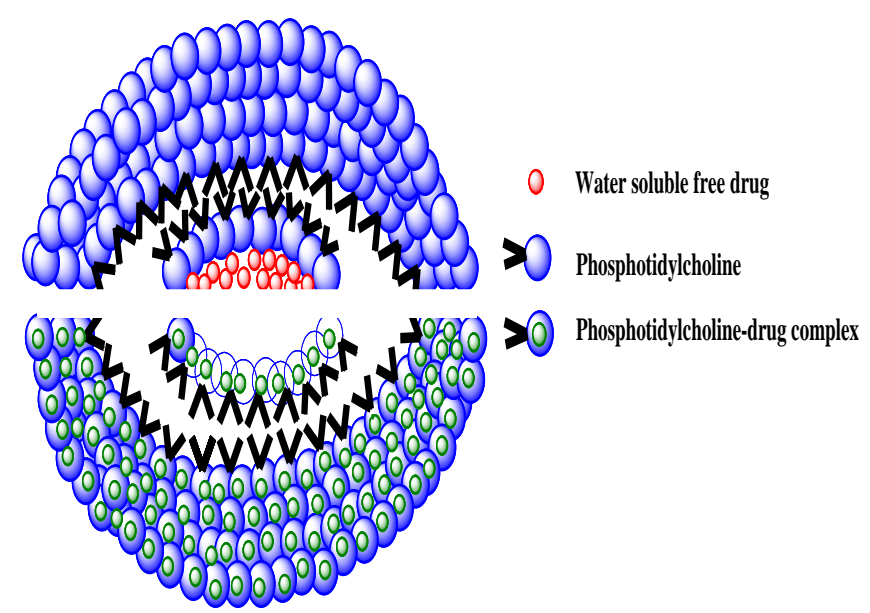

Figure 1 Schematic representation of the differences between liposome (upper segment) and Phytosome (lower segment).

\section{Properties of Phytosome:}

Following are some of the most relevant properties of Phytosome:

- Physicochemical properties

- Biological properties

\section{Physicochemical properties}

- Phytosome, a product is obtained from the stoichiometric reaction between phospholipid and plant extracts. ${ }^{10}$
- Phytosome size varies from $50 \mathrm{~nm}-100 \mu \mathrm{m} .{ }^{11}$

- Similar to liposome, phytosome assumes a micellar shape upon treatment with water and analysis can be done under photon correlation spectroscopy (PCS). ${ }^{4}$

- ${ }^{1} \mathrm{H}-\mathrm{NMR}$ and ${ }^{13} \mathrm{C}-\mathrm{NMR}$ analysis indicates that long aliphatic chains are wrapped around the active principle which produces lipophilic envelope. ${ }^{12}$

- Solubility of Phytosomeis mentioned below: ${ }^{13,14}$

○ soluble in aprotic solvents

- moderately soluble in fats

$\circ$ insoluble in water

- relatively unstable in alcohol

\section{Biological properties:}

- Phytosome are better absorbed and having more bioavailability than the conventional herbal extract or non-complex extracts which is demonstrated by pharmacokinetic and pharmacodynamics studies. ${ }^{13}$

\section{Advantages of Phytosome:}

Some of the advantages of Phytosome are mentioned below under: ${ }^{14,15}$

- Phosphatidylcholine is a part of cell membrane and also a major component of Phytosome plays dual role 1) nourishes skin besides acting as a carrier and 2) hepatoprotective effect and also approved for pharmaceutical use.

- In Phytosome, the absorption and bioavailability of aqueous soluble phytoconstituents is increased which potentiates therapeutic effect and reduces the desirable dose.

- The stability of Phytosome is better than liposome because chemical bonding is present $\mathrm{n}$ Phytosome but absent in the liposome.

- Nutritional value of the plant extract is increased due to the presence of phospholipids.

- The method of preparation of Phytosome is relatively simple.

- Phytosomecan permeate easily through skin.

- The water soluble phytoconstituents can be protected from destruction by digestive enzyme and gut bacteria because of phospholipid layer.

- Phytosome, is also a good option for systematic targeting.

\section{Disadvantage:}

Although Phytosome having so many advantages but instead of that this technology has some disadvantages like rapidly elimination of phytoconstituents from the Phytosome. ${ }^{4}$ 


\section{Indo Global Journal of Pharmaceutical Sciences, 2018; 8(3): 119-123}

\section{Methods of preparation for Phytosome:}

Phytosome is hybrid complex with polar bonding between standardized herbal extract anda phospholipid like phosphatidylcholine (PC), phosphatidyl ethanolamine or phosphatidylserine. Phytosome are manufactured by stoichiometric reactions carried out in aprotic solvents like acetone or dioxane with very less amount of a natural or synthetic phospholipid with herbal extract and product can be isolated by precipitation and spray drying. ${ }^{11}$

\section{Characterization and evaluation of Phytosome:}

Characterization and evaluation of Phytosome can be done based upon the following parameters such as: ${ }^{11}$

- Shape - can be visualized and characterized by Transmission Electron Microscopy (TEM)

- Particle size - can be determined by zeta potential by Dynamic Light Scattering (DLS) and photon correlation spectroscopy

- Percentage drug release, quality and purity of the material - can be determined by high performance liquid chromatographic (HPLC)

- Membrane permeability, distribution and surface tension activity - can be measured by the ring method in a $\mathrm{Du}$ Nouy Ring Tensiometer

- Entrapped volume of drug or solutes - can be measured by the Ultracentrifugation technique

- Chemical composition and transition temperature - can be measured by Differential Scanning Colorimeter

- To determine the interaction between phytoconstituents and phospholipid, the following spectroscopic techniques are used for the evaluation of Phytosome formulation: ${ }^{11}$

- FTIR (Fourier Transform Infra-red spectroscopy) - a useful tool for evaluation of Phytosome stability and to check the formation of the complex.

- $\quad{ }^{1} \mathrm{H}-\mathrm{NMR}$ and ${ }^{13} \mathrm{C}$-NMR - for identification of proteins and other complex molecules and also provides detailed information about the structure, dynamics, reaction state, and chemical environment of molecules.

- For biological evaluation of Phytosome using in-vitro and in-vivo models can be selected based upon the phytoconstituents the therapeutic activity which are present in the formulation. For example, for the assessment of ant-diabetic Phytosome formulation, the blood glucose or sugar is analyzed. ${ }^{11}$

\section{Phytosome applications in the treatment of different diseases:}

There are number of plant extract or phytoconstituents that are incorporated in the Phytosome technology are reported in the literature but some examples are from them such as Ginkgo biloba, Grape seed, Hawthorn, Milk thistle, Green tea, and Ginseng. Phytosome technology used in the treatment of various diseases and has shown a therapeutic effects like antidiabetic, anti-inflammatory, hepatoprotective effect, liver protectant, in hepatitis, cirrhosis, and fatty infiltration of the liver. ${ }^{11}$ Number of standardized extract with flavonoids and polyphenolic demonstrated an improved bioavailability when transformed in Phytosome. The study of silybin in rats showed increased bioavailability in the form of silybin phospholipid complex or phytosome. The absorption of silybin was increased seven times from silybin phytosome formulation when comparison was doen with the absorption of silybin from regular milk thistle extract. ${ }^{16,17}$ The hepatoprotective activity of silymarin phtosome was enhanced in comparison of silymarin alone against the toxic effects of aflatoxin $\mathrm{B}_{1} \cdot{ }^{17}$ Ginkgo phytosome, prepared from Ginkgo bilobaleaves showed better therapeutic effects in the treatment of Raynaud's disease and intermittent circulationin comparison to the conventional standardized plant extract. ${ }^{18}$ Grape seed extract (Vitisvinifera) Phytosome which is composed of oligomeric polyphenols and complexed with phospholipids has shown an increase in an antioxidant activity. ${ }^{19,20}$ In standardized Green tea extract (Theasinensis), epigallocatechin 3-O-gallate, is the key compound which is responsible for various pharmacological activities such as antidiabetic, antioxidant, anticancer, antiatherosclerosis, antihypercholesterolemic, cardioprotective, and antibacterial activities. To overcome the poor oral bioavailability of the Green tea leaves extract or polyphenols complex was prepared with phospholipids in the form of Phytosome. ${ }^{21,22}$ Diabetes mellitus is the result of improper secretion of insulin leading to increase in blood glucose level. Hyperlipedemia and hyper aminoacidemia are also present in diabetic patients. However, a diabetic patient may also suffer from neuropathy, nephropathy, cardiovascular and cerebrovascular diseases. Due to the harmful side effects of currently available antidiabetic drug, research for new anti-diabetic drugs have been significantly increasing with special focus on phytopharmaceutivcals. ${ }^{23}$ Quercetin and Hesperidin Phytosome showed more anti-diabetic activity in comparison of phytoconstituents alone. ${ }^{21}$

From past few years scientists are working on new standardized herbal extract to formulate Phytosome for increasing bioavailability. Some examples of Phytosome formulation of extracts from different sources such as Serenoa repens, Vaccinium myrtillus(Fruit extract), Coleus forskohlii, Santalum album, Aesculus hippocastanum, Ruscus aculeatus have been highly investigated for better bioavailability and therapeutic effect as compared to the conventional plant 
Indo Global Journal of Pharmaceutical Sciences, 2018; 8(3): 119-123

extracts. ${ }^{24}$ Some commercially available Phytosome products are mentioned below in Table 1.

Table 1Commercially available Phytosome products, ${ }^{6,24}$

\begin{tabular}{|c|c|c|c|}
\hline $\begin{array}{l}\text { Phytosom } \\
\text { e } \\
\text { product }\end{array}$ & $\begin{array}{l}\text { Phytoconstituents } \\
\text { of plants present in } \\
\text { Phytosome }\end{array}$ & $\begin{array}{l}\text { Dos } \\
\text { e }\end{array}$ & $\begin{array}{l}\text { Indications or } \\
\text { uses }\end{array}$ \\
\hline $\begin{array}{l}\text { Silybin } \\
\text { Phytosome } \\
\text { TM }\end{array}$ & $\begin{array}{l}\text { Silybin from } \\
\text { Silybummarianum }\end{array}$ & $\begin{array}{l}120 \\
\mathrm{mg}\end{array}$ & $\begin{array}{l}\text { Hepatoprotecti } \\
\text { ve, antioxidant }\end{array}$ \\
\hline $\begin{array}{l}\text { Hawthorn } \\
\text { Phytosome } \\
\text { TM }\end{array}$ & $\begin{array}{l}\text { Flavonoids from } \\
\text { Crataegus sp. }\end{array}$ & $\begin{array}{l}100 \\
\mathrm{mg}\end{array}$ & Nutraceutical \\
\hline $\begin{array}{l}\text { Ginseng } \\
\text { Phytosome } \\
\text { TM }\end{array}$ & $\begin{array}{l}37.5 \% \\
\text { ginsenosides from } \\
\text { immunomodulator } \\
\text { Panax ginseng } \\
\end{array}$ & $\begin{array}{l}150 \\
\mathrm{mg}\end{array}$ & $\begin{array}{l}\text { Nutraceutical } \\
\text { and } \\
\text { immunomodul } \\
\text { ator }\end{array}$ \\
\hline $\begin{array}{l}\text { Green Tea } \\
\text { Phytosome } \\
\text { тм }\end{array}$ & $\begin{array}{l}\text { Epigallocatechin } \\
\text { from Thea sinensis }\end{array}$ & $\begin{array}{l}50 \\
\text { to } \\
100 \\
\mathrm{mg}\end{array}$ & $\begin{array}{l}\text { Nutraceutical, } \\
\text { systemic } \\
\text { antioxidant. } \\
\text { anticancer }\end{array}$ \\
\hline $\begin{array}{l}\text { Ginkgo } \\
\text { biloba } \\
\text { Phytosome } \\
\text { TM }\end{array}$ & $\begin{array}{l}24 \% \\
\text { Ginkgoflavonglycos } \\
\text { ides } \\
\text { from Ginkgo biloba }\end{array}$ & $\begin{array}{l}120 \\
\mathrm{mg}\end{array}$ & $\begin{array}{l}\text { Protects brain } \\
\text { and vascular } \\
\text { lining, anti- } \\
\text { ageing agent. }\end{array}$ \\
\hline $\begin{array}{l}\text { Grape } \\
\text { Seed } \\
\text { Phytosome } \\
\text { TM }\end{array}$ & $\begin{array}{l}\text { Procyanidins from } \\
\text { Vitis vinifera }\end{array}$ & $\begin{array}{l}50- \\
100 \\
\mathrm{mg}\end{array}$ & $\begin{array}{l}\text { Nutraceutical, } \\
\text { systemic } \\
\text { Antioxidant, } \\
\text { anti-diabetic } \\
\text { and protects } \\
\text { against heart } \\
\text { disease }\end{array}$ \\
\hline $\begin{array}{l}\text { Bilberry } \\
\text { Phytosome }\end{array}$ & $\begin{array}{l}\text { Extract of Bilberry } \\
\text { which provides } \\
\text { anthocyanosides }\end{array}$ & - & $\begin{array}{l}\text { Improve } \\
\text { capillary tone, } \\
\text { reduce } \\
\text { abnormal } \\
\text { bloodvessel } \\
\text { permeability, } \\
\text { potent } \\
\text { antioxidant }\end{array}$ \\
\hline $\begin{array}{l}\text { Super Milk } \\
\text { thistle } \\
\text { extract }^{\mathrm{TM}} \\
\end{array}$ & $\begin{array}{l}\text { Silybin from } \\
\text { Silymarin Food } \\
\text { Product }\end{array}$ & $\begin{array}{l}150 \\
\mathrm{mg}\end{array}$ & $\begin{array}{l}\text { Antioxidant for } \\
\text { liver and skin }\end{array}$ \\
\hline $\begin{array}{l}\text { Centella } \\
\text { Phytosome }\end{array}$ & Terpenes & - & $\begin{array}{l}\text { Used to treat } \\
\text { Vein and skin } \\
\text { disorders }\end{array}$ \\
\hline
\end{tabular}

\section{CONCLUSION}

Phytosome technology is the advance form of herbal extract or phytochemicals delivery that possess a better absorption of drug and more therapeutic effect as compared to conventional herbal drug delivery system. Phytosome serves as a bridge between conventional drug delivery system and novel drug delivery system with an improved pharmacokinetic and pharmacological effect which is useful in the treatment of various diseases.

\section{REFERENCES}

1. Kumar AB, Prasanna H, Lakshman T, Prabha H, Kumar RS. Phytosomes as Novel Drug Delivery System for Herbal Medicine -A Review. Syst Rev Pharm. 2017;8(1):5-7. doi:10.5530/srp.2017.1.2.

2. Puranik N, Kammar KF, Devi S. Anti-diabetic activity of tinospora cordifolia (Willd.) in streptozotocin diabetic rats; does it act like sulfonylureas? Turkish J Med Sci. 2010;40(2):265270. doi:10.3906/sag-0802-40.

3. Maiti R, Das UK, Ghosh D. Attenuation of hyperglycemia and hyperlipidemia in streptozotocin-induced diabetic rats by aqueous extract of seed of Tamarindus indica. Biol Pharm Bull. 2005;28(7):1172-1176. doi:10.1248/bpb.28.1172.

4. Saha, Sanjay, Anupam Sarma, Pranjal Saikia TC. Phytosome : A Brief Overview. Sch Acad J Pharm. 2013;2(2):12-20.

5. Shivanand P, Kinjal P. Phytosomes: Technical revolution in phytomedicine. Int J PharmTech Res. 2010;2(1):627-631.

6. Amin T, Bhat SV. A Review on Phytosome Technology as a Novel Approach to Improve The Bioavailability of Nutraceuticals. Int $J$ Adv Res Technol. 2012;1(3):1-15. https://www.researchgate.net/publication/232244782_A_Review _on_Phytosome_Technology_as_a_Novel_Approach_to_Impro ve_The_Bioavailability_of_Nutraceuticals.

7. Sharma S. PHYTOSOMES : AN EMERGING TECHNOLOGY. Int J Pharma Res Dev. 2010;2(5):1-7.

8. Bombardelli E, Cristoni A, Morazzoni P. PHYTOSOME®s in functional cosmetics. Fitoterapia. 1994;65(5):387-401. http://www.embase.com/search/results?subaction=viewrecord\&f rom=export\&id=L24350089http://sfx.umd.edu/hs?sid=EMBAS E\&issn=0367326X\&id=doi:\&atitle=PHYTOSOME®s+in+funct ional+cosmetics\&stitle=FITOTERAPIA\&title=Fitoterapia\&vol ume $=65 \&$ issue $=5 \&$ spage $=387 \&$ epage .

9. Dubey Darshan, Satyaendra Shrivastava, Shweta Kapoor DP. Phytosome: A Novel Dosage Structure. Pharm Rev. 2007:1. http://www.oalib.com/paper/2258353\#.WoRfmKiWbIU. Accessed February 14, 2018.

10. Pajardi G, Bortot P, Ponti V, Novelli C. Clinical usefulness of oral supplementation with alpha-lipoic Acid, curcumin phytosome, and B-group vitamins in patients with carpal tunnel syndrome undergoing surgical treatment. Evid Based Complement Alternat Med. 2014;2014:891310. doi:10.1155/2014/891310.

11. Amit P, Tanwar YS, Rakesh S. Phytosome: Phytolipid Drug Dilivery System for Improving Bioavailability of Herbal Drug. $J$ Pharm Sci Biosci Res. 2013;3(2):51-57.

12. Dayan N, Touitou E. Carriers for skin delivery of trihexyphenidyl $\mathrm{HCl}$ : ethosomes vs. liposomes. Biomaterials. 2000;21(18):1879-1885.

13. Facino R, Carini M, Aldini G, Bombardelli E, Morazzoni P, Morelli R. Free radicals scavenging action and anti-enzyme activities of procyanidines from Vitis vinifera. A mechanism for their capillary protective action. Arzneimittelforschung. 1994;44(5):592-601.

14. Jain N, Gupta BP, Thakur N, et al. Phytosome: A Novel Drug Delivery System for Herbal Medicine. Int J Pharm Sci Drug Res. 2010;2(4):224-228. www.ijpsdr.com. 
Indo Global Journal of Pharmaceutical Sciences, 2018; 8(3): 119-123

15. Kidd P, Head K. A review of the bioavailability and clinical efficacy of milk thistle phytosome: A silybinphosphatidylcholine complex (Siliphos??). Altern Med Rev. 2005;10(3):193-203.

16. Busby A, Grange L La, Edwards J, King J. The Use of a Silymarin/Phospholipid Compound as a Fetoprotectant from Ethanol-Induced Behavioral Deficits. J Herb Pharmacother. 2002;2(1):39-47. doi:10.1080/J157v02n01_06.

17. Tedesco D, Steidler S, Galletti S, Tameni M, Sonzogni O, Ravarotto L. Efficacy of silymarin-phospholipid complex in reducing the toxicity of aflatoxin Blin broiler chicks. Poult Sci. 2004;83(11):1839-1843. doi:10.1093/ps/83.11.1839.

18. La Grange L, Wang M, Watkins R, et al. Protective effects of the flavonoid mixture, silymarin, on fetal rat brain and liver. $J$ Ethnopharmacol. 1999;65(1):53-61. doi:10.1016/S03788741(98)00144-5.

19. Barzaghi N, Crema F, Gatti G, Pifferi G, Perucca E. Pharmacokinetic studies on IdB 1016, a silybinphosphatidylcholine complex, in healthy human subjects. Eur $J$ Drug Metab Pharmacokinet. 1990;15(4):333-338. doi:10.1007/BF03190223.

20. Naik SR, Panda VS. Hepatoprotective effect of Ginkgoselect Phytosome ${ }^{\circledR}$ in rifampicin induced liver injurym in rats: Evidence of antioxidant activity. Fitoterapia. 2008;79(6):439445. doi:10.1016/j.fitote.2008.02.013.

21. Maiti K, Mukherjee K, Gantait A, Nazeer Ahamed H, Saha BP, Kumar Mukherjee P. Enhanced Therapeutic Benefit of QuercetinPhospholipid Complex in Carbon TetrachlorideInduced Acute Liver Injury in Rats: A Comparative Study. Iran J Pharmacol Ther. 2005;4(2):84-90. http://ijpt.tums.ac.ir/index.php/ijpt/article/view/050402084.

22. Sindhumol PG, Thomas M, Mohanachandran PS. Phytosomes: A novel dosage form for enhancement of bioavailability of botanicals and neutraceuticals. Int $J$ Pharm Pharm Sci. 2010;2(4):10-14.

23. Upendra Rao M, Sreenivasulu M, Chengaiah B, Reddy KJ, Chetty CM. Herbal Medicines for Diabetes Mellitus: A Review. Int J PharmTech Res. 2010;2(3):1883-1892.

24. Moscarella S, Giusti A, Marra F, et al. Therapeutic and antilipoperoxidant effects of silybin-phosphatidylcholine complex in chronic liver disease: Preliminary results. Curr Ther Res. 1993;53(1):98-102. doi:10.1016/S0011-393X(05)80160-2.

Indo Global Journal of Pharmaceutical Sciences( ISSN 22491023 ; UGC Journal No.: 44477; CODEN- IGJPAI; NLM ID: 101610675) indexed and abstracted in EMBASE(Elsevier), UGC Journal List, National Library of Medicine (NLM) Catalog, Elsevier( EMBASE), ResearchGate, Publons, CAS (ACS), Index Copernicus, Google Scholar and many more. For further details, visit http://iglobaljournal.com 